\title{
MEDICAL AND SOCIAL EXAMINATION: THEORETICAL AND LEGAL ASPECT
}

\section{Triukhan O. A.}

\section{INTRODUCTION}

The Constitution of Ukraine (Art. 3) states an individual, his life and health, honor and dignity, inviolability and security shall be recognized in Ukraine as the highest social value. Human rights and freedoms, and guarantees thereof shall determine the essence and course of activities of the State ${ }^{1}$.

The relevance of this research involves reforming the system of sociomedical examination. Literature draws attention to the need for establishing an independent expert commission. Moreover, most citizens' appeals concern the violation of the rights of persons with disabilities. There are widespread cases when the rights of persons with disabilities, who really need social protection of the state, are limited and systematically violated. The above practice is confirmed by numerous complaints and media publications about the abuses of the Medical and Social Expert Commission (MSEC). Unfortunately, many persons with disabilities also associate MSEC with emotional humiliation. It is believed that persons with disabilities are people who need the support of the state and others as no one else.

Individual aspects of the protection of the rights of persons with disabilities are covered in the studies by V.S. Andreiev, N.B. Bolotina, M.O. Buianov, V.S. Venediktov, V.M. Dohadov, V.V. Zhernakov, T.Z. Harasymov, H.S. Honcharov, M.L. Zakharov, S.I. Kobzev, S.I. Bohdanov, O.Ie. Machulska, V.V. Moskalenko, P.D. Pylypenko, O.I. Protsevskyi, N.M. Stakhovska, Ye.H. Tuchkov, Ya.M. Fohel, M.I. Fliaster, O.M. Yaroshenko et al. The issues devoted to the foreign experience of social protection of the population, in general, and social protection of people with disabilities, in particular, are considered in the contributions of the following scientists: S. Didyk, L. Berezovska, N. Bondar, O. Zaiarnyk et al. Despite the availability of some scientific papers, the author believes the issue under consideration is poorly studied, and some problems in this area remain unaddressed.

Considering the above, the purpose of the research is to specify provisions related to the enjoyment of the rights of persons with disabilities while undergoing medical and social examination and make forward proposals for improving the relevant legislation.

${ }^{1}$ Конституція України від 28 червня 1996 р. Відомості Верховної Ради Украӥни. 1996. № 30. Ст. 141. 


\section{The historical and legal aspect of the establishment and development of a medical and social examination}

Throughout the world, the emphasis is laid on the social protection of persons with disabilities that people with disabilities don't face a prejudiced attitude. It is noteworthy that in some countries, equality between persons with disabilities and other members of society is enshrined at the constitutional level. Thus, according to the Basic Law of the Federal Republic of Germany (Art. 3), no person shall be disfavored because of disability (physical or mental) ${ }^{2}$. Similar provisions are consolidated in the constitutions of Canada (Art. 15), Switzerland (Art. 8), and Armenia (Art. 14.1). The Portuguese Constitution contains a separate article, 71 "people with disabilities", which regulates their rights. The Constitution of Spain (Art. 49) fixes the responsibilities of public authorities concerning persons with disabilities ${ }^{3}$. It should be highlighted that national law prohibits disability discrimination ${ }^{4}$.

A medical and social examination plays a special part in the system of social security measures. Some scientists working on this issue note that the medical and social examination has passed certain stages. Literature notes that the history of the formation, establishment and development of public administration of the service of medical and social examination in Ukraine has permitted identifying three stages. Its origins date back to the $17^{\text {th }}$ century.

The article focuses on the fact that the first stage $\left(17^{\text {th }}\right.$ century -1917$)$ is a stage of private-oriented social support of persons with disabilities. It was the period of laying the groundwork of expert work on the principles of social interaction, and thus, in literature, it is conditionally called the stage of private-oriented social support of persons with disabilities ${ }^{5}$.

Therefore, M.K. Khobzei asserts that in 1908, the first medical advice bureaus (MAB) were created in Katerynoslav (now Dnipro). Since then, the active development of a specialized network of institutions for medical disability examination (Kharkiv, Baku, Odesa) has begun. At that time, bureaus were created at the initiative of the medical community, and therefore, their structure was developed on the ground. Most of them were private institutions, the main task of which involved assessing the working capacity of patients taking into account the nature of the disease or injury. MABs, which were located at city

${ }^{2}$ Основний Закон Федеративної Республіки Німеччини від 23 травня 1949 р. URL: http://concourt.am/armenian/legal_resources/world_constitutions/constit/germany/ german-r.htm.

Конституція Королівства Іспанії від 27 грудня 1978 р. URL: http://www.uznal.org/constitution.php?text=Spain@language=r.

4 Про основи соціальної захищеності осіб 3 інвалідністю в Україні : Закон України від 21 березня 1991 р. № 875-XII. Відомості Верховної Ради УРСР. 1991. № 21. Ст. 252 (дата звернення: 28.04.2021).

5 Іпатов А.В., Хожило І.І. Історичні аспекти становлення служби медикосоціальної експертизи життєдіяльності осіб з особливими потребами в Україні. URL. http://www.dbuapa.dp.ua/zbirnik/2010-01/10iavopu.pdf. 
hospitals, consisted of three to five doctors. Thus, the foundation of MABs was a progressive step in establishing the service for medical and social examination of working capacity ${ }^{6}$.

The second stage (1917-1990) is a stage of state compensatory social support for people with disabilities. It should be noted that after 1917, the issue of setting up the state system of medical and labor examination emerged full blown. Thus, in 1928, the "Regulations on Medical Expert Commissions" were approved whereby the medical expert commissions (MEC) were renamed.

In addition, A.V. Ipatov and I.I. Khozhylo, in one of their scientific works, draw attention to the fact that the 1948 period of formation of the service of medical and social examination of working capacity had certain features, in particular, the first All-Russian Congress of Medical Experts was held. It is noted that a few decades ago, there was the service of medical and labor examination (MLE). In the context of public aid, medical and labor expert commissions (MLEC) conducted citizens' examination. Literature draws attention to the fact that in 1948, the Resolution of the Council of Ministers of the USSR No. 4149 approved the Regulations on Medical and Labor Expert Commissions, according to which the main tasks of MLECs were expanded with an emphasis on prevention and rehabilitation.

A noteworthy detail is that since 1991, the history of the medical and social examination of life has faced the third stage - a stage of developing state foundations of social integration and reintegration of individuals with disabilities. After Ukraine's independence, the principles of providing medical and social help changed. First of all, a reduced vital activity, not the loss of ability to work, turned to be the main criterion for disability under international standards ${ }^{7}$. In this regard, according to the Regulations on Individual Rehabilitation and Adaptation Program of a Person with a Disability approved by the Decision of the Cabinet of Ministers of Ukraine dated 22.02.1992, No. 83 (the Regulations became invalid in 2009), MLECs were renamed medical and social expert commissions ${ }^{8}$.

It is expedient to mention that the USSR had a single state social welfare system for persons with health conditions associated with disability ${ }^{9}$. The adoption of the Law of Ukraine "On the Fundamentals of Social Protection of Persons with Disabilities in Ukraine" dated 1991 resulted in a positive

6 Хобзей М.К. Аналіз сучасного стану реабілітації інвалідів в Україні. URL: http//cyberleninka.ru/article/n/analiz-suchasnogo-stanu-reabilitatsiyi-invalidiv-vukrayini/viewer/ (дата звернення: 28.04.2021).

Международная классификация функционирования, ограничений жизнедеятельности и здоровья / перевод Г.Д. Шостка, В.Ю. Ряснянский, А.В. Квашин и др. Женева : ВОЗ, 2001. 342 с.

${ }^{8}$ Нормативно-правові матеріали 3 питань інвалідності (короткий довідник) / уклад. М.Ю. Малий. Дніпропетровськ, 2006. 458 с.

Справочник документов по трудоустройству инвалидов / под ред. П.А. Маккавейского. Ленинград : Медицина, 1981. 575 с. 
moment involving social guarantees for persons with disabilities and introducing the concept "medical and social examination". Since the adoption of the Law of Ukraine "On the Rehabilitation of People with Disabilities in Ukraine" dated 2005, an attitude towards the rehabilitation of people with disabilities has changed for the better.

Disability confirmation in Ukraine is carried out exclusively by MSEC. In Ukraine, the functioning of the medical and social examination is tied to many problems (in particular, a lack of transparency of work and public control and the imperfection of regulatory support). The practice shows that people with disabilities face numerous problems related to the violations of their rights on a daily basis. The author highlights the exercise of the rights of persons with disabilities while undergoing a medical and social examination also remains challenging.

It is necessary to establish a fact that many key international statutory acts were adopted. The Universal Declaration of Human Rights, which was proclaimed by the United Nations General Assembly on 10 December 1948, is still the main global statutory act. Thus, Art. 1 proclaims: "All human beings are born free and equal in dignity and rights" $"$. The Convention on the Rights of Persons with Disabilities and its Optional Protocol, which had been adopted by the United Nations General Assembly dated 13.12.2006 (Resolution 61/106) and went into effect dated 03.05.2008, are integral to the development of international cooperation in terms of the rights of persons with disabilities ${ }^{11}$. Moreover, it refers to many acts of the International Labor Organization (ILO) which deal with the social support of workers who have sustained serious health damages due to a work-related accident or disease that have led to disability, in particular, Employment Injury Benefits Convention, 1964, (No. 121) (Recommendation 121), Medical Care and Sickness Benefits Convention, 1969 (No. 130) (Recommendation 134) etc. It is worth mentioning that the issue under study is regulated at the European level by documents on human rights: specifically European Social Charter (Revised) regulates the protection of human rights in those social spheres in which persons with disabilities face numerous restrictions and discrimination.

One should give credit to national legislation that has a statutory basis for the medical and social examination. The Constitution of Ukraine is the basic statutory act. Moreover, MSEC is currently guided by laws and subordinate legislation: i.e., Fundamentals of Healthcare Legislation dated 19.11.1992, the Law of Ukraine "On Amending Certain Laws of Ukraine to Improve

10 Загальна Декларація прав людини: прийнята i проголошена резолюцією 217 А (III) Генеральної Асамблеї ООН від 10 грудня 1948 р. Офіиійний вісник України. 2008. № 93. Ст. 3103.

11 Конвенція ООН про права осіб 3 інвалідністю, прийнята резолюцією Генеральної Асамблеї ООН 13 грудня 2006 p. URL: http://zakon.rada.gov.ua (дата звернення: 28.04.2021). 
some Aspects of Discharge of Military Duty" dated 05.04.2018, the Law of Ukraine "On Amending Art. 7 of the Law of Ukraine "On the Rehabilitation of Persons with Disabilities" to Assess Disability" dated 13.03.2018, the List of anatomic defects, other irreversible dysfunctions of organs and body system under which the relevant disability group is established without indicating re-examination term" approved by the Cabinet of Ministers of Ukraine dated 21.01.2015, No 10, and others. There is a good deal of internal instructions and orders the MSEC staff relies on, as follows: the Order of the Ministry of Health of Ukraine "On the Approval of the Forms of an Individual Rehabilitation Program of a Person with a Disability, a Child with a Disability and Preparation Procedure" dated 08.10.2007, No. 623, the Order of the Ministry of Health of Ukraine "On the Approval of Forms of Primary Accounting Documentation used by the Medical and Social Expert Commissions" dated 30.07.2012, No 577, the Order of the Ministry of Health of Ukraine "On Approval of the Procedure and Criteria for the MSEC Assessment of Percentage Permanent Disability of Workers who Sustained Work-Related Damages" dated 05.06.2012, No 420, and others regulating legal relations in the relevant area.

Despite the recent adoption of regulations on the social protection of persons with disabilities, improvement of their access to medicine, education, employment, physical facilities: the Law of Ukraine "On Rehabilitation in the of Health Care Sphere" dated 03.12.2020, the Decree of the President of Ukraine "On Improving the Effectiveness of Measures in the Field of the Rights of Persons with Disabilities" dated 03.12.2019, a legal framework of medical and social care in Ukraine needs further advancement. A positive fact is that in 2020, work upon the development of the Concept of reforming medical and social examination in Ukraine started; it is formulated proposals for the draft order of the Cabinet of Ministers of Ukraine "On Amending the Order of the Cabinet of Ministers of Ukraine dated 03.12.2009, No 1317”. In the author's opinion, such a step is urgently needed and relevant.

It is worth mentioning that on 14.04.2021, the Cabinet of Ministers of Ukraine approved the Decision "On Amending the Decision of the Cabinet of Ministers of Ukraine dated 05.04.2012, No 321", according to which the Procedure for providing technical and other rehabilitation means for persons with disabilities, children with disabilities and other certain categories of the population and monetary compensation for self-purchased technical and other rehabilitation means has been significantly changed. It is also expedient emphasize that the procedure for obtaining technical rehabilitation means by persons with disabilities is simplified: persons with disabilities have been provided with expanded options for submitting documents for 
technical and other rehabilitation means, and on June 1, 2021, persons with disabilities obtained additional guarantees ${ }^{12}$.

It is undeniable that one can't ignore that on June 2, 2021, the Government approved the draft Order of the President of Ukraine "On the Delegation of Ukraine to Participate in the 14th session of the Conference of State Parties to the UN Convention on the Rights of Persons with Disabilities". The draft proposes to form a Ukrainian delegation to join the 14th session of the Conference of State Parties to the UN CRPD and approve instructions for the Ukrainian delegation. The participation in the mentioned event will confirm that the course towards European integration and further democratization is crucial for Ukraine. This will also contribute to laying the groundwork for the use of the UN potential principally in the context of strengthening social justice and protection of the rights of persons with disabilities; introducing best practices to improve the state policy of Ukraine in the field of enforcement of the rights and meeting the needs of persons with disabilities on an equal footing with other citizens; advancing their living conditions in accordance with the Convention on the Rights of Persons with Disabilities ${ }^{13}$.

One can conclude the protection of the rights of the vulnerable social group holds relevance. The author believes international-legal and national aspects of protection of the rights of persons with disabilities, including their legal status in society, need rethinking and revaluating given global changes in the world.

\section{Current status and directions for improving MSEC in terms of disability confirmation: contemporary problems}

According to Art. 1 of the Law of Ukraine "On the Rehabilitation of Persons with Disabilities in Ukraine" dated 06.10.2005, a medical and social examination is the establishment of the degree of permanent physical impairment, disability group, causes and time of their onset as well as the finalization and approval of an individual rehabilitation program for a person with a disability (a child with a disability) under the compensation strategy based on an individual rehabilitation plan and comprehensive rehabilitation examination of a person with a physical disability ${ }^{14}$.

The issue of rehabilitation and disability verification has always been relevant. It is worth mentioning the MSEC's main task is to rehabilitate persons with disabilities. The author marks that 363 MSECs were functioning in Ukraine (as of 2020). In addition, the Ukrainian system of medical and

12 Про внесення змін до постанови Кабінету Міністрів України від 05 квітня 2012 р. № 321 : постанова Кабінету Міністрів України від 14 квітня 2021 р. № 362. Офіиійний вісник України. 2021. № 33. Ст. 1943.

13 Міністерство соціальної політики України. URL: https://www.msp.gov.ua/ news/20143.html.

${ }_{14}$ Про реабілітацію осіб з інвалідністю в Україні : Закон України від 06 жовтня 2005 р. № 2961-IV. Відомості Верховної Ради Украӥни. 2006. № 2. Ст. 36. 
social expert commissions is still subordinated to the Ministry of Health, not the central executive authority realizing social policy as is the case in European countries (Germany, Finland, Sweden, Norway, and France).

It should be emphasized MSEC is tasked to determine working capacity in general and the degree of loss of occupational capacity that is regulated by the Order of the Cabinet of Ministers of Ukraine "Issues of Medical and Social Examination" No 1317 dated 03.12.2009. Thus, according to the Regulations on medical and social examination dated 03.12.2009, patients who have reached the age of majority, persons with disabilities, victims of work-related accidents and diseases undergo a medical and social examination to establish the degree of physical impairment, causes, time of onset, disability group and compensation-adaptation abilities of a person, the realization of which facilitates medical, psychological and pedagogical, professional, work, fitness-sport, physical and social rehabilitation ${ }^{15}$.

The above statutory act (item 10) stipulates that depending on the degree of loss, type of disease and disability group, general and specialized commission are created. A commission consists of at least three doctors whose specializations are approved by the Ministry of Healthcare, taking into account commission scope, rehabilitation specialist, clinical psychologist or psychologist.

It is important to note the major tasks of a medical and social examination are the following: an evidence-based assessment of human physical dysfunction, including the state of working capacity, determination of the group, cause and time of the onset of a disability upon various diseases, injuries and mutilations; the study of causes of a disability, development and implementation of measures aimed at preventing temporary incapacity to work and disability; organization and carrying out rehabilitation activities and specification of evidence for various types of social assistance to patients and persons with disabilities; an assessment of public health and a forecast of the dynamics of morbidity and primary disability, etc.

To undergo a medical and social examination, one has to take such steps: to apply to a health care institution at the place of residence; to undergo a complete medical check up to determine a diagnosis and assess social needs; to receive a referral of the medical and preventive treatment facility to MSEC.

Following the examination results, MSEC provides an individual, who is recognized to be a person with a disability, with a standard certificate specifying a disability group and an individual rehabilitation program (hereinafter referred to as "IRP"). It is essential to dwell on the procedure of disability confirmation which is regulated by the Instruction to establish a disability group approved by the Order of the Ministry of Health of Ukraine

15 Питання медико-соціальної експертизи : постанова Кабінету Міністрів України від 03 грудня 2009 р. № 1317. Офіиійний вісник України. 2009. № 95. Ст. 3265 (дата звернення: 28.04.2021). 
dated 05.09.2011, No $561^{16}$. Thus, legislation registers three disability groups (I, II or III disability group). The author stresses that the I disability group is divided into sub-groups (A and B) based on the degree of physical impairment of a person and the need for permanent external care, help or supervision.

The research marks there was the Soviet percentage system for establishing the degree of disability, but it didn't prove its value as the percentage relied on the professional capabilities of citizens. 5-6 - group disability classification had been used before 1932, and 3 - group classification was introduced in 1932. Subsequently, the practice of medical and labor examinations revealed some shortcomings in the 1932 Instruction in terms of disability groups; in 1956, it was amended to clarify the criteria for identifying a disability group and give specific examples. In Soviet times, permanent physical impairment was the primary cause of disability. All it took was the factual findings of functional disorder.

Literature highlights that some foreign countries solely establish the percentage of disability. In addition, mass media has elucidated information that the Ukrainian government intends to give up on the disability grading system available since the Soviet era. Instead, there are plans to switch to the International Classification of Functioning, Disability and Health (ICF) applied in the European Union. The ICF won approval from all 191 World Health Organization (WHO) member states on May 22, 2001, during the $54^{\text {th }}$ World Health Assembly. The general scale can be described as follows: no problems (none, absent, negligible): 0-4\%; mild problems (slight, low): 5-24\%; moderate problems (medium, fair): 25 - 49\%; severe problems (high, extreme): $50-95 \%$. Moreover, it is expected that social policy for persons with disabilities and relevant payments will rely on the percentage of disability, not the groups as before. This approach is recommended by the World Health Organization.

The experience of the Republic of Latvia in identifying and confirming a disability group seems to be interesting to borrow. Latvian medical legislation qualifies disability and predictable disability. In particular, the legislation stipulates that according to the current standards, a predictable disability is functional limitations caused by an illness or injury that may result in disability if the necessary medical and rehabilitation services are not provided. Under the Latvian legislation, an individual, who is recognized to be a person with a disability, receives a document confirming the relevant status. The Cabinet of Ministers regulates the document sample, procedure of issuance and registration. Disability is established for persons under the

16 Про затвердження Інструкції про встановлення груп інвалідності : наказ Міністерства охорони здоров'я України від 05 вересня 2011 р. № 561. Офіиійний вісний Украӥни. 2011. № 91. Ст. 3319. 
age of 18 without division into groups ${ }^{17}$. Taking into account the Latvian experience, it is essential to statutorily adopt a simplified procedure of undergoing a medical and social commission for people with anatomic defects and severe disease through its remote implementation without a patient. In addition, it is crucial to fix the procedure for engaging experts and specialist upon the initiative of a person who is subjected to examination to avoid corruption practices.

It is interesting to note that the analysis of social welfare legislation of EU countries shows that the medical diagnosis is a major factor in recognizing a person as "a person with a disability". Thus, for example, in Lithuania, Sweden, and Finland, qualified doctors are engaged to confirm the presence of disability: approved medical practitioners and social insurance doctors; in Germany family physicians; in Great Britain - specially trained physicians; in the Netherlands - both social security doctors and labor experts. However, the medical team doesn't decide on providing aid - it does an authorized public officer. Literature states that foreign countries still don't have a unified scheme for determining disability. Thus, the degree of disability is stipulated by such a criterion as the level of working capacity (Lithuania - up to 55\%, Moldova - up to $45 \%$ ); the loss of working capacity (Finland - by $40 \%$, Sweden - by $25 \%$; Israel, Switzerland - 50\%, Italy - 66\%; Latvia - 25\%); work decrement (the Netherlands - by 35\%; France - at least by $10 \%$ ); total incapacity for work (Great Britain).

National legislation specifies that MSEC specialists are obliged to inform a person (a legal representative) about the procedure, conditions and criteria for establishing disability and clarify other issues associated with determining a disability group at the request of the person (a legal representative) or in case of disagreement with the MSCE decision. One should take into account that the commission examines a temporarily disabled person, who addressed for disability confirmation, within seven days as from the date of receipt of MSEC documents. If the commission has not decided to extend the period of temporary incapacity for work, the certificate of incapacity for work shall be dismissed on the examination date, but not later than the date of the identification of a person's disability group. The date of the disability identification is considered the day of receipt by MSEC of the documents required for the examination of the patient. The author stresses that the head of members of the commission, who are guilty of making the wrong decision and illegally issuing disability documents, are liable under the law.

MSEC renews the disability status from the date of its suspension, but not more than for three years, if the term of re-examination of the person is missed for valid reasons. It is worthwhile mentioning that in the case of

17 Лист Посольства України в Латвійській Республіки «Щодо практики встановлення інвалідності в Латвійській Республіці» від 16 травня 2011 р. № 6129/13-500-428. URL: https://latvia.mfa.gov.ua/ 
deterioration of health, one can contact the medical institution at the place of residence to set the medical grounds for re-referral of medical records to MSEC for examination. The re-examination of persons with disabilities, including unstable, reversible changes and disorders of organs and body systems, is conducted in 1-3 years to assess the effectiveness of rehabilitation treatment and rehabilitation measures, health status and the degree of social adaptation. The reconsideration of previously specified terms for persons with disabilities (citizens whose disability is established without mentioning re-examination term) is exercised upon the changes of health condition and ability to work or when facts of abuse or mistakes made in establishing the disability group are revealed.

One should pay attention to the fact that in case of disagreement of the patient at inspection with the MSEC decision, he has the right to submit a written application to the MSEC, where he was examined, or the relevant health department (office) within a month. Within three days from the date of receipt of the application, the commission that conducted the examination or the health department (office) shall send all available documents together with the application for consideration of the central commission of MSEC which, no later than one month from the date of submission of the application, conducts re-examination of the patient and makes the appropriate decision.

It is expedient to highlight the basic tool of rehabilitation measures is an individual rehabilitation program for persons with disabilities. Regulations on an individual rehabilitation program of a person with a disability dated 23.05.2007, No 757, identifies the mechanism of running and financing IRP of a person with a disability ${ }^{18}$. The author emphasizes IRP of a person with a disability is drawn up individually for every person with a disability based on the State Standard Program of Rehabilitation of Persons with Disabilities approved by the Decision of the Cabinet of Ministers dated 08.12.2006, No $1686^{19}$.

The author points out that an individualized rehabilitation program is developed for a month as from the date of application. Unfortunately, MSEC doctors don't always draw up IRP in full. In the author's opinion, the very imperfection of IRP content and insufficient recommendations for medical or vocational rehabilitation result in incomplete adaptation of persons with disabilities that cause negative for society socio-economic effects.

It is stressed that one of the most significant powers of MSEC involves drawing up IRP for persons with disabilities which specifies types of rehabilitation measures and performance period. The author marks that the

18 Про затвердження Положення про індивідуальну програму реабілітації особи 3 інвалідністю : постанова Кабінету Міністрів України від 23 травня 2007 р. № 757. URL: http://w1.c1.rada.gov.ua/.

19 Про затвердження Державної типової програми реабілітації осіб 3 інвалідністю : постанова Кабінету Міністрів України від 08 грудня 2006 р. № 1686. Офічійний вісник України. 2006. № 50. Ст. 3311. 
development of IRP of a person with a disability is a complicated and responsible piece of work. The development and performance of IRP of a person with a disability are often followed by many challenges. Judicial practice shows that quite often persons with disabilities apply to the court to declare unlawfulness of the denial to adjust IRP, the obligation to make adjustments in IRP. In particular, the above is exemplified by the decision of Donetsk District Administrative Court in the case No. 200/8252/19-a, which is recorded in the Unified State Register of Court Decisions ${ }^{20}$.

Literature notes case law protects the rights of citizens if IPR is not implemented (http://www.reyestr.court.gov.ua/ Review/11598069) ${ }^{21}$. In the author's opinion, it is essential to put an increased focus on the procedure for arranging and completing IRP of a person with a disability. In addition, case law does not always protect the rights of citizens if IPR of persons with disabilities is not implemented. It is worth drawing attention to case law, in particular, the Decision of Khmelnytskyi District Administrative Court in the case No 560/1809/19. Thus, the plaintiff appealed to the court with a claim in which he asks to recognize the actions and inaction of the defendants towards the intentional deprivation of rehabilitation, habilitation services, sanatorium-resort treatment, which is prescribed by the State Standard Program of Rehabilitation of Persons with Disabilities and is state guarantees of persons with disabilities during IRP validity, illegal and compensate moral damages. Having examined the evidence available in the case file, the court held that the defendant acted legally when developing IPR of a person with a disability ${ }^{22}$.

The research focuses on the need to improve the effectiveness of preparation and performance of IRP of persons with disabilities and enhance control over the preparation and performance of IRP of persons with disabilities. Thus, appropriate drafting of IRP of persons with disabilities is a required condition for further positive changes in the health of a person with a disability. Therefore, it is expedient to emphasize that advancing the social protection of persons with disabilities in Ukraine, including upgrading the quality of medical examinations, timeliness and reasonability of referral of citizens for medical and social examination, is obvious. Public health is one of the greatest values and a necessary criterion for the country's socioeconomic development.

Literature highlights that MSEC is considered to be one the most corrupted establishments in the field of state social policy. It is not unusual

\footnotetext{
20

Рішення Донецького окружного адміністративного суду у справі № 200/8252/19-a. Єәиний державний реєстр судових рішень. URL: https://youcontrol.com.ua/catalog/court-document/84919488/.

${ }^{21}$ Багній М., Коваль О., Яцків Т. Стан медико-соціальної експертизи в Україні та шляхи покращення іiі реалізації: громадський аналіз та рекомендації. URL: http://www.irf.ua/files/ukr/programs/health/ph-2014-1-24.pdf.

22 Рішення Хмельницького окружного адміністративного суду у справі № 560/1809/19. URL: http://youcontrol.com.ua/catalog/court-document/83904880.
} 
that one can bribe disability and related pension in MSECs. There are widespread violations and limitations of the rights of persons with disabilities who really need state social protection. The beforementioned is confirmed by media publications on corruption and abuses in MSEC ${ }^{23}$.

It is essential to establish a fact that persons appealing to confirm disability are subjected to examination. However, due to the corruption factor and a lack of transparency of procedures, MSEC functioning is associated with many weaknesses - one of them is the re-examination of persons with disabilities for the confirmation of their status. In particular, citizens lodge complaints against MSEC decisions about disability and undertaking re-examinations because MSEC conclusions, according to plaintiffs, don't meet their actual health conditions. The above issues are particularly relevant to the citizens whose disability group has a specified period of validity, and after its completion, they shall undergo MSEC health checkup. The complainants also demanded to clarify the procedure and criteria for identifying the disability of persons with long-term dysfunctions.

Analyzing case law in terms of MSEC examination of citizens, one can assess the judicial protection of the rights of persons with disabilities, become acquainted with real-life cases submitted to the court and specify the problems citizens most often face. Mass media states that the Unified State Register of Court Decisions encompasses sentences for bribes during disability granting. Mass media notes that, unfortunately, only one sentence provided for jail term for a bribe-taker ${ }^{24}$. To confirm the abovementioned, one should pay attention to case law, in particular, case No 333/6365/17 of Komunarskyi District Court of Zaporizhzhia ${ }^{25}$.

In the author's opinion, undergoing a medical and social examination the procedure of which needs transparency - remains relevant to citizens. In the context of MSEC practices, it is worth remarking that this is a sensitive issue for our country: according to the explanatory note to the Draft Law of Ukraine "On Amending Certain Laws of Ukraine on Improving Social Protection of Persons with Disabilities in Ukraine" dated 13.06.2016, No 4803 (withdrawn on 29.08.2019), "activities of the commissions have non-transparent and close nature". There is a real need for creating an independent expert commission. Thus, draft law No 4803 focuses on the quality of drawing up IRP of persons with disabilities, which is mainly

${ }^{23}$ Про внесення змін до деяких законів України щодо підвищення соціальної захищеності інвалідів в Україні : проект Закону України від 13 червня 2016 р. № 4803. URL:http://w1.c1.rada.gov.ua/ (дата звернення: 28.04.2021).

24 «Місце торгу та корупції»: розслідування про роботу медико-соціальних експертних комісій. UA: Периий / Білецька І., Бондар Д., Садовник А., Стратонов О., Ульянова O. URL: https://4vlada.com/mistse-torgu-ta-koruptsii-rozsliduvannia-pro-robotumedyko-sotsialnyh-expertnyh-komisij (дата звернення: 28.04.2021).

${ }_{25}$ Рішення Комунарського районного суду у справі № 333/6365/17. Сдиний держсавний реєстр судових рішень. URL: http://www.reyestr.court.gov.ua/Review/ 82647944 (дата звернення: 28.04.2021). 
implemented by the representatives of the medical sector, within the MSEC system. Unfortunately, the quality of IRP is in the doldrums. The author considers this deprives millions of persons with disabilities in Ukraine of the opportunities for effective social integration and full-quality life and foredooms them to social isolation. Consequently, the proposal for substantial improvement of the effectiveness of drawing up and execution of IRP of persons with disabilities, including intensification of the control over the preparation and execution of IRP of persons with disabilities, seems to be expedient.

\section{Procedure for appealing against MSEC decisions: a review of current case law}

The Constitution of Ukraine stipulates that everyone shall be guaranteed the right to appeal to a court and judicial protection (Arts. 55, 124).

Legal literature interprets the protection of rights as the resolution of disputes between interested individuals and legal entities when one of the parties to the dispute believes that its rights have been violated.

Citizens often complain about MSEC decisions on a disability group and re-examinations. It should be noted that, in practice, the plaintiffs complain that MSEC findings do not correspond to the actual state of their health. These issues are especially relevant to citizens whose disability group has a certain period of validity and, after its completion, they shall undergo MSEC re-examination.

According to Art. 6 of the Law of Ukraine "On the Fundamentals of Social Protection of Persons with Disabilities in Ukraine" dated 21.03.1991, a citizen has the right to appeal to a court the decision of MSEC establishments about the recognition or non-recognition of one as a person with a disability. It should be emphasized that the defendant in this case is the relevant MSEC.

According to p. 1, Art. 5 of the Code of Administrative Procedure of Ukraine dated 06.07.2005 (hereinafter referred to as "CAPU"), everyone has the right to apply to an administrative court if he believes that the decision, action or omissions of the power entity violates his rights, freedoms or interests ${ }^{26}$.

It should be noted that a dispute against MSEC decisions, actions or omissions has public law nature and shall be considered under the rules of administrative procedure. Thus, Art. 19 of CAPU provides for cases that fall under the jurisdiction of administrative courts. Para. 9, p. 1 of Art. 19 of CAPU prescribes that the jurisdiction of administrative courts is extended to the cases of public law disputes, including disputes concerning appeals against decisions of attestation, competition, MSEC and other similar bodies, which are binding on public authorities, local governments and others.

\footnotetext{
${ }^{26}$ Кодекс адміністративного судочинства України : Закон України від 06 липня 2005 p. № 2747-IV. URL: http://zakon0.rada.gov.ua/laws/show/2747-15.
} 
According to p. 1, Art. 25 of CAPU, administrative cases challenging individual acts, actions or omissions of power entities, which are accepted (committed, admitted) towards a particular natural or legal person (their associations), are decided by the administrative court at the plaintiff's choice at the place of his residence (stay, location) that is registered in the manner prescribed by law or by the administrative court at the defendant's location, except for cases specified by CAPU.

As for the terms of the statement of claim and its consideration, it should be noted that a person may appeal against the MSEC decision by filing a statement of claim in an administrative court no later than 6 months from the date when the person learned or had to learn of the violation.

It is essential to mark that in accordance with p. 4 of Art. 122 of CAPU, if the law provides for the option of pre-trial dispute resolution and the plaintiff resorts to this procedure or the law provides for the mandatory pretrial dispute resolution, it is set a three-month period calculated from the date of informing the plaintiff about the outcome of his complaint against decisions, actions or omissions of the power entity in order to apply to the administrative court.

One also should take into account that p. 1 of Art. 193 of CAPU stipulates that the court shall initiate proceedings on the merits no later than sixty days from the date of commencement of proceedings, and in case of extension of the term of preliminary proceedings - no later than the next day from the date of expiration of such term.

The analysis of legal rules shows that MSEC decisions are aimed at ensuring the implementation of state policy in the field of rehabilitation of persons with disabilities, creating legal, economic, political, socio-domestic and socio-psychological conditions to meet their needs for health restoration, financial security, feasible labor and social activities and relate exclusively to the relevant persons in terms of such decisions. Thus, MSEC is a power entity only in vertical relationship with persons a particular decision refers to.

A general rule asserts that one government body cannot file a lawsuit against another body because this means a claim of the state to itself, except for "competent disputes" (p. 40) as provided for in procedural legislation. It is necessary to point out the mentioned legal reasoning is fixed in the decision of the Grand Chamber of the Supreme Court (hereinafter "GCSC") dated 16.09.2020. Thus, under the case No 821/1524/17 of the mentioned GCSC decision, the issue of jurisdiction and powers to appeal against the MSEC decision is studied ${ }^{27}$. Relying on the content of the above rule, the jurisdiction of an administrative court covers the cases of appealing against the decisions of MMC (military medical commission) and MSEC, and the appealer is exclusively the person against whom the decision was made. In

\footnotetext{
${ }^{27}$ Постанова Великої Палати Верховного Суду від 16 вересня 2020 р. у справі № 821/1524/17. Сдиний державний реєстр судових рішень. URL: https://ips.ligazakon.net/document/view/C014901.
} 
addition, GCSC has already presented a legal reasoning of legal disputes about appealing against the decisions of a MSEC body, in particular, in the decisions dated 13.03.2019 in the case No 526/2339/17 and dated 26.06.2019 in the case No 201/11696/18.

By analyzing case law, it should be noted that the following decision of the GCSC in the case No 201/11696/18, which determined the jurisdiction of disputes with MSEC, is noteworthy. The Chamber holds that a dispute about appealing against actions or omissions committed by MSEC shall be considered under the rules of administrative procedure. As the subject matter of the dispute is an appeal against the decision of the MSEC body, the lower courts, in compliance with the requirements of procedural law, concluded that it is impossible to consider the dispute in civil proceedings. Thus, in October 2018, the plaintiff appealed to the court to declare the decision of the regional MSEC about the refusal of recognizing him as a person with a disability to be illegal and to oblige the defendant to recognize him as a person with a disability of the II group. The Order of Zhovtnevyi District Court of Dnipropetrovsk dated 31.10.2018 denied commencing proceedings based on p. 1 of Art. 186 of the Civil Procedure Code (CPC) of Ukraine since the case is not subject to consideration in civil proceedings. The court of first instance reasoned the decision using the fact that the dispute is under administrative jurisdiction. The Court of Appeal agreed with the findings of the court of first instance. The plaintiff filed a cassation appeal, arguing that the dispute shall be considered in civil rather than administrative proceedings, as it concerns the health of an individual that is a personal nonproperty right, which is particularly protected under civil law (Art. 275 of the Civil Code of Ukraine) or originates from the employment relationship due to the plaintiff's work-related injury sustained when performing employment duties. Thus, the Chamber states that a dispute about appealing against actions or omissions committed by MSEC has public law nature and shall be considered under the rules of administrative procedure ${ }^{28}$.

Attention should be paid to the fact that there is another legal reasoning of GCSC, in particular, GCSC brought on a case No 490/9823/16-ц. Therefore, the plaintiff, who is a retiree of the Ministry of Internal Affairs of Ukraine, challenged the MSEC refusal to admit that his disability is associated with discharging of employment duties and assign him a status of veteran, and thus, the Pension Fund would recalculate his pension. The Central District Court of Mykolayiv refused to initiate proceedings on the grounds that the defendant (MSEC) is subordinated to the Ministry of Health, and therefore, is a state body. This means the case shall be considered according to the rules of administrative procedure. The Court of Appeals of Mykolayiv Oblast concluded that MSEC activity involves

\footnotetext{
${ }^{28}$ Постанова Великої Палати Верховного Суду від 26 червня 2019 р. у справі № 201/11696/18. Єдиний державний реєстр судових рішень. URL: https://reyestr.court.gov.ua/Review/82997480.
} 
performing managerial duties and making decisions, which cause some legal effects, and upheld the decision of the court of first instance. In the cassation appeal, the plaintiff referred to p. 10 of the Resolution of the Plenum of the Supreme Specialized Court of Ukraine for Civil and Criminal Cases "On Some Issues of the Jurisdiction of General Courts and Jurisdiction of Civil Cases". It states that cases of appealing against MSEC decisions shall be considered under civil procedure, as such disputes relate to the health of an individual, which is his personal non-property right protected by the rules of civil law. It is noted that a dispute about appeals against decisions, actions or omissions committed by MSEC has public law nature and shall be considered under the rules of administrative procedure. However, as mentioned earlier, in this case, the court of first instant refused to initiate proceedings pointed out that the dispute had to be considered under the rules of administrative procedure. Therefore, according to p. 5 of Art. 170 of CAP, a further appeal of the same person to the administrative court concerning the same subject matter and grounds and the same defendant, in respect of whom the decision to refuse to initiate proceedings was rendered, is not allowed. Under such conditions, the plaintiff could be deprived of the right to access to a court and an effective remedy. Consequently, taking into account the jurisdictional conflict and imperative instruction of p. 2 of Art. 170 of CAP, the Grand Chamber decided the case had to be considered under the rules of civil procedure ${ }^{29}$.

The author states that scores of people, who have serious health complications, experience difficulties in acquiring the official status of a person with a disability. The above is evidenced by case law. Stated claims concerning the declaration of actions and decisions of MSEC about disability confirmation and the degree of disability to be illegal are unreasonable and unfounded. Case law shows the dispute arose because the plaintiff disagreed with the defendant's conclusions about the confirmation of the third disability group and $60 \%$ disability for the relevant period indefinitely. Attention is paid to the fact that the cassation appeal is based on arguments that the lower courts did not take into account the provisions of Criteria 238, according to which, in the plaintiff's opinion, his illnesses afford grounds for $100 \%$ disability. It is necessary to point out that the panel of judges of the Supreme Court falls into line with the conclusions of the lower courts on the refusal to satisfy the plaintiff's claim in this pArt. In addition, the panel of courts also emphasizes that the arguments put forward by the plaintiff both during the consideration of the case in the courts of first and appellate instance and in cassation appeal are reduced to disagreement of the plaintiff with the MSEC decision on the third disability group and 60\% working capacity, because the plaintiff believes that he should be assigned

\footnotetext{
${ }^{29}$ Постанова Великої Палати Верховного Суду від 12 грудня 2018 р. у справі № 490/9823/16-ц. Сдиний державний реєстр судових рімень. URL: https://reyestr.court.gov.ua/Review/7897752.
} 
the first disability group and $100 \%$ loss of working capacity. At the same time, the analysis of the specified rules of the current legislation permits deducing that the MSEC decision is rendered after the full medical examination of the person and carrying out inspections by a medical and preventive treatment facility and pursuant to medical records based on objective examination of the person by commission members ${ }^{30}$.

Another example of case law states that determining the degree of loss of health requires a medical degree and expertise. The reason for filing a lawsuit in the court was illegal, in the plaintiff's opinion, refusal to assign him the III disability group indefinitely. In particular, by the decision of the inter-district MSEC, the citizen was assigned the III disability group due to a nonindustrial disease for 1 year. After medical examinations conducted from 2015 to 2017, the III disability group due to a non-industrial disease was prolonged each time taking into account the need for active restorative treatment and rehabilitation. However, the re-examination resulted in the denial to recognize the person as a person with the III disability group. Thus, the citizen filed a lawsuit against the regional MSEC seeking the revocation of the decision of MSEC No 2 about the refusal to recognize him as a person with the III disability group and compelling the defendant to render the decision about granting him the status of a person with the III disability group. In reasoning the stated claims, the plaintiff referred to the fact that his health had not improved and remained unchanged for five years, which is the basis for recognizing him as a person with a disability indefinitely, and that, in 2019, he was re-assigned the III disability under the same circumstances. Case law shows that Vinnytsia District Administrative Court rejected a complaint in full ${ }^{31}$.

It is interesting that the panel of judges of the Seventh Administrative Court of Appeal partially upheld the appeal, in particular, regarding the revocation of the disputed decision of the regional MSEC No 2 about the refusal to grant the III disability group indefinitely. However, it agreed with the position of the court of first instance that determining the degree of loss of health and the degree of physical dysfunction is discretionary powers of the relevant commissions and requires a medical degree and expertise. Therefore, the court cannot replace other government body and take over the settlement of issues that are under the jurisdiction of this body by law ${ }^{32}$.

${ }^{30}$ Постанова Верховного Суду від 30 квітня 2021 р. у справі № 160/12235/19. Сдиний державний реєстр судових рімень. URL: https://reyestr.court.gov.ua/ Review/96685064.

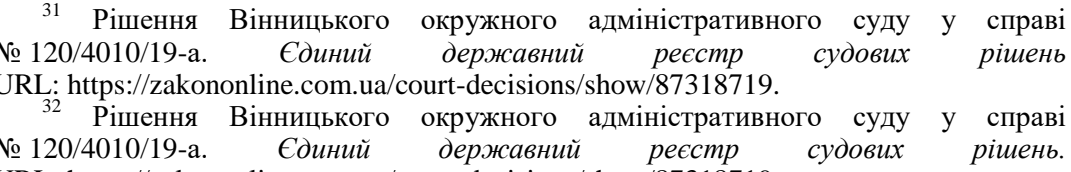
URL: https://zakononline.com.ua/court-decisions/show/87318719. 
Consequently, the solution to the problem of ensuring the rights of persons with disabilities as one of the most vulnerable segments of the population is currently quite relevant to Ukraine, both at the scientific and practical levels. There are many causes, including the poor-quality work of government agencies and, principally, the unwillingness of society itself to recognize the equality between the rights of persons with disabilities and the rights of all others.

It is worthwhile mentioning that MSEC competence involves raising public awareness about medical and social examination. In the author's opinion, it is necessary to improve legal awareness through conducting outreach activities both by non-governmental organizations, mass media and MSEC, state authorities and local self-government. Thus, it seems expedient to highlight that the need for the law promoting the social protection of people with disabilities in Ukraine is obvious.

\section{CONCLUSIONS}

Taking into the abovementioned, the legal framework of medical and social assistance in Ukraine needs further improvement. It would make sense to mark that domestic medical and social assistance has had a thorny path: from providing people with disabilities with social support to the modern development of the system of medical and social examination and rehabilitation. As pointed out above, one of the most important powers of MSEC involves drawing up and amending IRP of persons with disabilities in which types of rehabilitation measures and their period of performance are specified. In the author's opinion, it is essential to improve the effectiveness of elaboration and execution of IRP of persons with disabilities. It is essential to stress that adequate arrangement of IRP of persons with disabilities is a necessary condition for further positive changes in the health of a person with a disability.

According to the author, the scientific position of some scholars, who work upon the issue under study, is worth supporting. In particular, V.P. Melnyk states that one of the scenarios of law development and implementation of principles of the UN Convention on the Rights of Persons with Disabilities is formulation and approval of the Code on the Rights of Persons with Disabilities, which would clearly and comprehensively regulate relationships of the social protection of persons with disabilities ${ }^{33}$.

The author specifies that the statutory framework is available, but it has some shortcomings which need statutory resolving that will contribute to the realization of medical and social examination and activities of the commission. As for changes in the approach to disability confirmation, first

33 Мельник В.П. Законодавчі засади правового регулювання реабілітації інвалідів: сучасний стан та напрями удосконалення. Часопис Національного університету «Острозька академія». Серія : Право. 2014. № 2. URL: http://nbuv.gov.ua/UJRN/Choasp_2014_2_22 (дата звернення: 28.04.2021). 
of all, it should mean not an expenditure recording but the first step towards rehabilitation to engage a person into full-quality life. Moreover, the author believes that forms of raising public awareness about medical and social examination also need proper statutory regulation. Consequently, it seems expedient to emphasize that the advancement of social protection of persons with disabilities in Ukraine, including upgrading the quality of medical check, timeliness and justification of the referral of citizens to medical and social examination, is evident.

\section{SUMMARY}

The article marks the disability issue has become particularly relevant to Ukraine. It is said that in our country, there has been a recent tendency towards a significant increase of persons with disabilities. The above is due to the general increase of persons with disabilities in the country that is specifically caused by military actions in eastern Ukraine.

Unfortunately, for many people who have serious health complications, it raises difficulties to be granted the official status "a person with a disability" that is confirmed by analyzed in the article case law. It is concluded that most often, MSEC refuses disability confirmation due to the following reasons: incomplete examination, insufficient justification of the disease; a lack of some (clarifying) medical records, and thus, it is impossible to determine the degree of disability; a lack of diagnoses or symptoms, etc.

Attention is paid to the fact that the core objective of MSEC is the rehabilitation of persons with disabilities. Many related scientific publications, which consist of scientists' proposals for improving the forward-looking legislation in terms of the manifestation of disability discrimination, have been studied.

It is justified that the state sets an important task: to create an unimpeded living environment that will assist in advancing the social adaptation of persons with disabilities. This will allow them to take an active part in social life.

The author draws general conclusions that the issue of the protection of persons with disabilities needs enhancing and puts forward proposals for updating legal regulation in the relevant field.

\section{REFERENCES}

1. Конституція України від 28 червня 1996 р. Відомості Верховної Ради Украӥни. 1996. № 30. Ст. 141 (дата звернення: 28.04.2021).

2. Основний Закон Федеративної Республіки Німеччини від 23 травня 1949 p. URL: http://www.rfhwb.de/Pravo/Pravo_ru/pravo_rul.htm.

3. Конституція Королівства Іспанії від 27 грудня 1978 p. URL: http://www.uznal. org/constitution.php?text=Spain@language=r.

4. Про основи соціальної захищеності осіб 3 інвалідністю в Україні : Закон України від 21 березня 1991 р. №875-XII. Biдомості Верховної Ради УРСР. 1991. № 21. Ст. 252 (дата звернення: 28.04.2021). 
5. Іпатов А.В., Хожило I.I. Історичні аспекти становлення служби медико-соціальної експертизи життєдіяльності осіб 3 особливими потребами в Україні. URL. http://www.dbuapa.dp.ua/zbirnik/201001/10iavopu.pdf.

6. Хобзей М.К. Аналіз сучасного стану реабілітації інвалідів в Україні. URL: http//cyberleninka.ru/article/n/analiz-suchasnogo-stanureabilitatsiyi-invalidiv-v-ukrayini/viewer/ (дата звернення: 28.04.2021).

7. Международная классификация функционирования, ограничений жизнедеятельности и здоровья / перевод Г.Д. Шостка, В.Ю. Ряснянский, А.В. Квашин и др. Женева : ВОЗ, 2001. 342 с.

8. Нормативно-правові матеріали 3 питань інвалідності (короткий довідник) / уклад. М.Ю. Малий. Дніпропетровськ, 2006. 458 с.

9. Справочник документов по трудоустройству инвалидов / под ред. П.А. Маккавейского. Ленинград : Медицина, 1981. 575 с.

10.Загальна Декларація прав людини: прийнята і проголошена резолюцією 217 А (III) Генеральної Асамблеї ООН від 10 грудня 1948 р. Офіиійний вісник Украӥни. 2008. № 93. Ст. 3103.

11. Конвенція ООН про права осіб 3 інвалідністю, прийнята резолюцією Генеральної Асамблеї ООН 13 грудня 2006 р. URL: http://zakon.rada.gov.ua (дата звернення: 28.04.2021).

12. Про внесення змін до постанови Кабінету Міністрів України від 05 квітня 2012 р. № 321 : постанова Кабінету Міністрів України від 14 квітня 2021 р. № 362. Офіиійний вісник Украӥни. 2021. № 33. Ст. 1943.

13. Міністерство соціальної політики України. URL: https://www.msp.gov.ua/news/20143.html.

14. Про реабілітацію осіб з інвалідністю в Україні : Закон України від 06 жовтня 2005 р. № 2961-IV. Відомості Верховної Ради України. 2006. № 2. Ст. 36.

15. Питання медико-соціальної експертизи : постанова Кабінету Міністрів України від 03 грудня 2009 р. № 1317. Офіиійний вісник Украӥни. 2009. № 95. Ст. 3265 (дата звернення: 28.04.2021).

16. Про затвердження Інструкції про встановлення груп інвалідності : наказ Міністерства охорони здоров'я України від 05 вересня 2011 р. № 561. Офіційний вісний Украӥни. 2011. № 91. Ст. 3319.

17. Лист Посольства України в Латвійській Республіки «Щодо практики встановлення інвалідності в Латвійській Республіці» від 16 травня 2011 р. № 6129/13-500-428. URL: https://latvia.mfa.gov.ua/.

18. Про затвердження Положення про індивідуальну програму реабілітації особи з інвалідністю : постанова Кабінету Міністрів України від 23 травня 2007 р. № 757. URL: http://w1.c1.rada.gov.ua/.

19. Про затвердження Державної типової програми реабілітації осіб 3 інвалідністю : постанова Кабінету Міністрів України від 08 грудня 2006 р. № 1686. Офіиійний вісник України. 2006. № 50. Ст. 3311. 
20. Рішення Донецького окружного адміністративного суду у справі № 200/8252/19-а. Єдиний державний реєстр судових рішень. URL: https://youcontrol.com.ua/catalog/court-document/84919488/.

21. Багній М., Коваль О., Яцків Т. Стан медико-соціальної експертизи в Україні та шляхи покращення ії реалізації: громадський аналіз та рекомендації. URL: http://www.irf.ua/files/ukr/programs/health/ ph-2014-1-24.pdf. (дата звернення: 28.04.2021).

22. Рішення Хмельницького окружного адміністративного суду у справі № 560/1809/19. URL: http://youcontrol.com.ua/catalog/courtdocument/83904880 (дата звернення: 28.04.2021).

23. Про внесення змін до деяких законів України щодо підвищення соціальної захищеності інвалідів в Україні : проект Закону України від 13 червня 2016 p. № 4803. URL: http://w1.cl.rada.gov.ua/ (дата звернення: 28.04.2021).

24. «Місце торгу та корупції»: розслідування про роботу медикосоціальних експертних комісій. UA: Перший / Білецька I., Бондар Д., Садовник А., Стратонов О., Ульянова O. URL: https://4vlada.com/mistsetorgu-ta-koruptsii-rozsliduvannia-pro-robotu-medyko-sotsialnyh-expertnyhkomisij (дата звернення: 28.04.2021).

25. Рішення Комунарського районного суду м. Запоріжжя у справі № 333/6365/17. Єдиний державний реєстр судових рімень URL: http://www.reyestr.court.gov.ua/Review/82647944 (дата звернення: 28.04.2021).

26. Про внесення змін до деяких законів України щодо підвищення соціальної захищеності інвалідів в Україні : проект Закону України від 13 червня 2016 p. № 4803. URL: http://w1.c1.rada.gov.ua/ (дата звернення: 28.04.2021).

27. Кодекс адміністративного судочинства України : Закон України від 06 липня 2005 p. № 2747-IV. URL: http://zakon0.rada.gov.ua/ laws/show/2747-15.

28. Постанова Великої Палати Верховного Суду від 16 вересня 2020 р. у справі № 821/1524/17. Сдиний держсавний реєстр судових рішень. URL: https://ips.ligazakon.net/document/view/C014901.

29. Постанова Великої Палати Верховного Суду від 26 червня 2019 р. у справі № 201/11696/18. Сдиний державний реєстр судових рішень. URL: https://reyestr.court.gov.ua/Review/82997480.

30. Постанова Великої Палати Верховного Суду від 12 грудня 2018 р. у справі № 490/9823/16-ц Сдиний державний реєстр судових рішень. URL: https://reyestr.court.gov.ua/Review/7897752.

31. Постанова Верховного Суду від 30 квітня 2021 р. у справі № 160/12235/19. Єдиний державний реєстр судових рімень URL: https://reyestr.court.gov.ua/Review/96685064.

32. Рішення Вінницького окружного адміністративного суду у справі № 120/4010/19-а. Єдиний державний реєстр судових рімень URL: https://zakononline.com.ua/court-decisions/show/87318719. 
33. Постанова Сьомого апеляційного адміністративного суду у справі № 120/4010/19-а. Сдиний державний реєстр судових рішень URL: https://reyestr.court.gov.ua/Review/90396477.

34. Мельник В.П. Законодавчі засади правового регулювання реабілітації інвалідів: сучасний стан та напрями удосконалення. Часопис Наџіонального університету «Острозька академія». Серія : Право. 2014. № 2. URL: http://nbuv.gov.ua/UJRN/Choasp_2014_2_22. (дата звернення: 28.04.2021).

Information about the author: Triukhan Oksana Anatoliivna, $\mathrm{PhD}$ in Law, Associate Professor, Senior Lecturer at the Department of Labor Law and Social Security Law National University "Odesa Law Academy" 23, Fontanska doroha str., Odessa, 65009, Ukraine 